\title{
膀胱腫瘍の前立腺浸潤様式の検討
}

\author{
東京慈恵会医科大学病理学教室（主任：藍沢茂雄教授） \\ 伊藤 貴章 和田 鉄郎 古里 征国 藍沢 茂雄
}

\section{PROSTATIC INVOLVEMENT OF BLADDER CARCINOMA}

Takaaki Ito, Tetsuro Wada, Masakuni Furusato and Shigeo Aizawa

Department of Pathology, Jikei University, School of Medicine

(Background) The histological pattern of prostatic involvement by transitional cell carcinoma is still unclear. The present study was carried out in bladder carcinoma with prostatic involvement to clarify the histological invasion pattern and its association with primary lesions.

(Methods) In the past 10 years, 83 cases of total cystectomy including prostatectomy underwent pathological diagnosis in our department. This study included 81 cases of transitional cell carcinoma (TCC), of which 11 showed prostatic involvement of bladder carcinoma. In these cases, the histological patterns of invasion were classified in relation to prostatic urethra, prostatic duct, stroma, lymphatic duct, capsule, vein and perineural invasion. Seventy cases without prostatic involvement were controls. The location, pathological grade, stage and lymphatic involvement of primary bladder carcinoma were compared in terms of prostatic involvement cases with control cases.

(Results) Among those 11 cases, there were 3 cases in which only the prostatic duct was involved, 2 cases with invasion to only lymphatic duct, and involvement of both in 6 cases. One case of the prostatic duct involvement showed non-continuous invasion in the prostatic duct without prostatic urethra invasion, suggesting the possibility that non-continuous invasion could occur as a type of multicentric growth of TCC.

(Conclusions) Suspected routes of invasion of bladder carcinoma into the prostate were; 1 continuous transductal, 2 trans-lymphatic ductal, 3a combination of the two. It appears necessary to consider the possibility of TCC occurring in the prostate simultaneously with bladder carcinoma as a part of multicentric growth. There was a tendency of prostatic involvement cases include the bladder neck and trigone, and show lymphatic duct involvement more than nonprostatic involvement cases.

Key words: bladder carcinoma, prostatic involvement, metastatic carcinoma of the prostate

要旨：(目的)膀胱腫瘍の前立腺浸潤例について検討し, その組織学的浸潤様式や原発巣との関連につい て明らかにすることを目的とした。

（方法）最近 10 年間に当教室にて病理診断を行った前立腺を含む膀胱全摘例は 83 例あり，このうち移 行上皮癌以外の 2 例を除いた, 前立腺浸潤11例と前立腺非浸潤例70例を対象とした。浸潤形態を前立腺 部尿道, 導管, 間質, 腺房, リンパ管との関係から分類し, 原発の膀胱腫崵の grade, 深達度, 腫崵の部 位との関連について検討した。

(結果) 導管への浸潤のみ認めた例が， 3 例，リンパ管浸潤のみ認めた例が 2 例，その両方を認めた 例が 6 例であった。導管浸潤例のうち 1 例は前立腺部尿道に侵襲なく導管に独立した移行上皮癌を認め た。前立腺浸潤例と非浸潤例の比較では, 前立腺浸潤を認めた例の方が原発巣が膀胱䅡部及び三角部を 含む例が有意に多く,リンパ管侵襲も有意に多かった。 
（結論）膀胱腫瘍の前立腺への浸潤経路としては 1 ，経導管摘連続浸潤， 2 ．経リンパ管浸潤， 3 . 混合型が考えられた。移行上皮癌の多中心性発生の一型として前立腺移行上皮癌が同時発生する可能性 が示唆された，原発巣が膀胱頝部及び三角部を含む場合，リンパ管侵襲を認める場合は，前立腺浸潤を 充分検索する必要があると思われた。

キーワード：膀胱腫瘍，前立腺浸潤，転移性前立腺癌

\section{緒言}

膀胱腫瘍の前立腺への浸潤は, Schell-hammer ら ${ }^{1)}$ は，膀胱腫瘍で膀胱全摘出術を施行した350例中42例， $12 \%$ に認めたと報告しており決して稀ではない。また 原発性前立腺移行上皮癌も多数報告されているが，こ れは膀胱癌（多発性尿路上皮癌）の一特殊型とすべき との意見 ${ }^{2} も あ り ，$ 膀胱腫瘍の前立腺進展様式はあま り明確ではない，今回我々は膀胱腫瘍の前立腺浸潤例 について検討し，その組織学的浸潤形態を明らかにす るとともに，非浸潤例との比較検討を行い，原発巣と の関連性についても検討した。

\section{対象・方法}

最近 10 年間に当教室にて病理診断を行った前立腺を 含む膀胱全摘例は83例であった。これらの前立腺はす べて尿道後面に直角になるような水平断で 4 ～ $5 \mathrm{~mm}$ の 連続切片を作製し HE 染色にて組織学的検討を行っ たところ12例に前立腺浸潤を認めた。うち腺癌であっ た 1 例を除いた 11 例（移行上皮癌）について前立腺へ の浸潤様式を前立腺部尿道, 導管, 間質, 腺房, リン パ管などとの関係から分類した。残りの前立腺非浸潤 例71例中，扁平上皮癌であった 1 例を除いた70例（移 行上皮癌）を対照に原発巣の膀胱腫瘍の grade，深達
度，膀胱内の腫瘍の占拠部位，リンパ管侵襲の有無に ついて前立腺浸潤例と比較検討した. grade について はgrade 3を含むか否かで，深達度については表在性 (腫瘍浸潤が粘膜下層まで) か否かで，占拠部位につい ては膀胱頸部及び三角部を含むかで分類し，比較検討 した。統計学的有意差検定には $\chi^{2}$ 検定を用いた。

\section{結 果}

1. 前立腺への浸潤形態

前立腺浸潤例について, 前立腺部尿道, 導管, リン パ管などへの浸潤の有無を表 1 にまとめた。前立腺導 管への浸潤のみの例が 3 例(表 1 , 症例 $1 \sim 3$ ), 前立 腺リンパ管侵襲のみ認めた例が 2 例（表 1 , 症例 4 , 5 ）その両方を認めた例が 6 例（表 1 , 症例 $6 \sim 11$ ） であった．前立腺導管への浸潤のみ認めた例では，全 例前立腺部尿道直下の導管のみの浸潤であった.また, 前立腺部尿道には浸潤は無く, 前立腺導管に独立した 移行上皮癌を認めた例（表 1 , 症例 9 ） があった。導 管浸潤例の組織像を示す (図 1 )。腫瘍細胞は前立腺導 管の basal cell の下方にもぐりこむような形で浸潤し ていた。図 2,3 に前立腺リンパ管侵襲例の組織像を 示した. また, 症例 6,7 では, 前立腺導管に沿って 小葉構造をとるかの如く浸潤していた（図 4 ).

表 1 前立腺への浸潤形態。導管，リンパ管，間質の浸潤は前立腺部尿道直下と深部に分け，深 部のものを間質内と記した

\begin{tabular}{|c|c|c|c|c|c|c|c|c|c|c|c|}
\hline \multirow{2}{*}{ 症例 } & \multicolumn{2}{|c|}{ 導管浸潤 } & \multicolumn{2}{|c|}{ リンパ管浸潤 } & \multirow{2}{*}{$\begin{array}{l}\text { 前立腺部 } \\
\text { 部 }\end{array}$} & \multicolumn{2}{|c|}{ 間質浸潤 } & \multirow{2}{*}{$\begin{array}{c}\text { 前立腺皮膜 } \\
\text { 浸潤 }\end{array}$} & \multirow{2}{*}{$\begin{array}{l}\text { 静脈 } \\
\text { 浸潤 }\end{array}$} & \multirow{2}{*}{$\begin{array}{l}\text { 神経線維 } \\
\text { 殒再唚襲 }\end{array}$} & \multirow{2}{*}{ 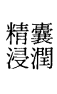 } \\
\hline & 尿道下 & 間質内 & 尿道下 & 間質内 & & 尿道下 & 間質内 & & & & \\
\hline 1 & + & - & - & - & denuded & - & - & - & - & - & - \\
\hline 2 & + & - & - & - & + & - & - & - & - & - & - \\
\hline 3 & + & - & - & - & + & - & - & - & - & - & - \\
\hline 4 & - & - & - & + & - & - & - & - & - & - & + \\
\hline 5 & - & - & + & + & + & - & - & - & - & - & - \\
\hline 6 & + & + & + & + & denuded & + & + & + & - & + & - \\
\hline 7 & + & + & + & + & + & + & + & + & - & + & - \\
\hline 8 & + & + & + & + & denuded & + & + & + & + & - & + \\
\hline 9 & + & - & + & - & - & + & - & - & - & - & - \\
\hline 10 & + & + & + & - & + & + & - & - & - & - & - \\
\hline 11 & + & + & + & - & denuded & - & - & - & - & - & - \\
\hline
\end{tabular}


図 1 前立腺導管の基底細胞の下にもぐりこむように移行上皮癌の浸潤を認める。 $\mathrm{H}$ \& E 染色, 200倍像.

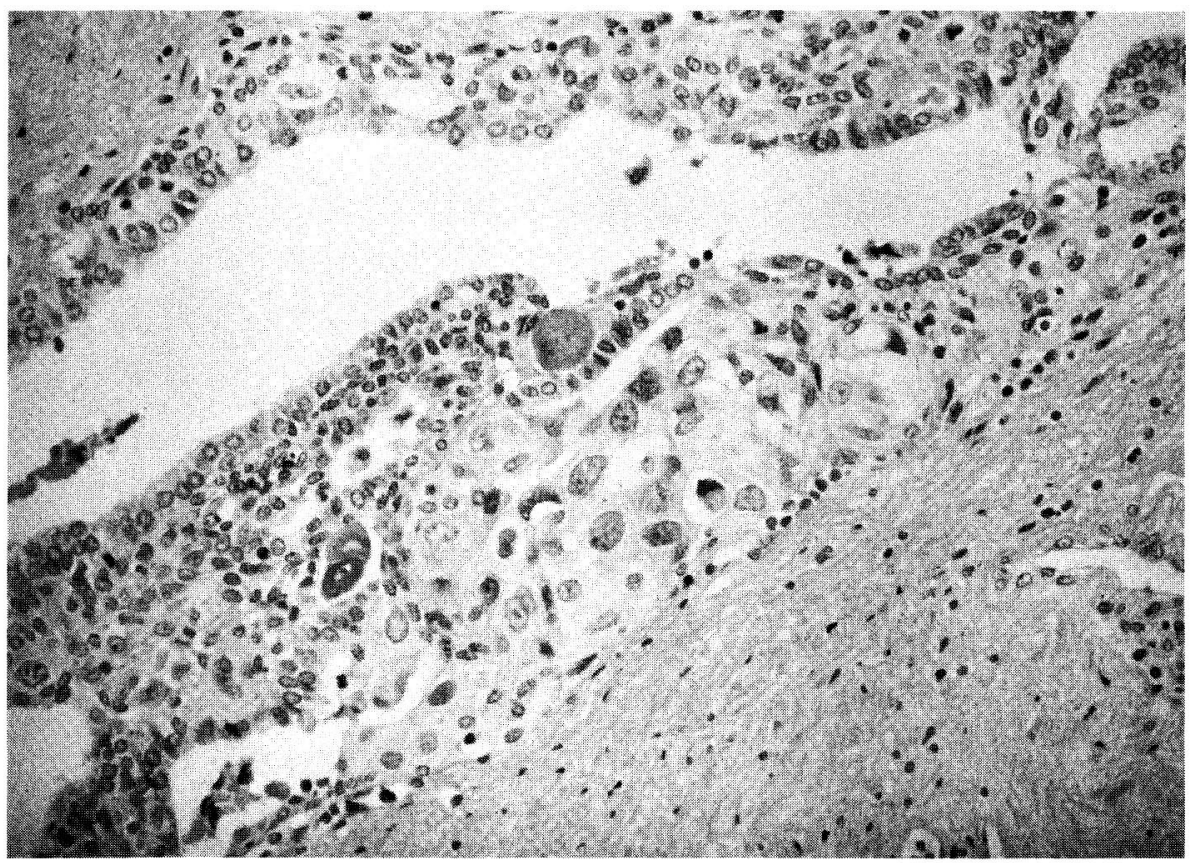

図 2 前立腺実質内のリンパ管に移行上皮癌の浸潤を認める. H \& E 染色，40倍像.

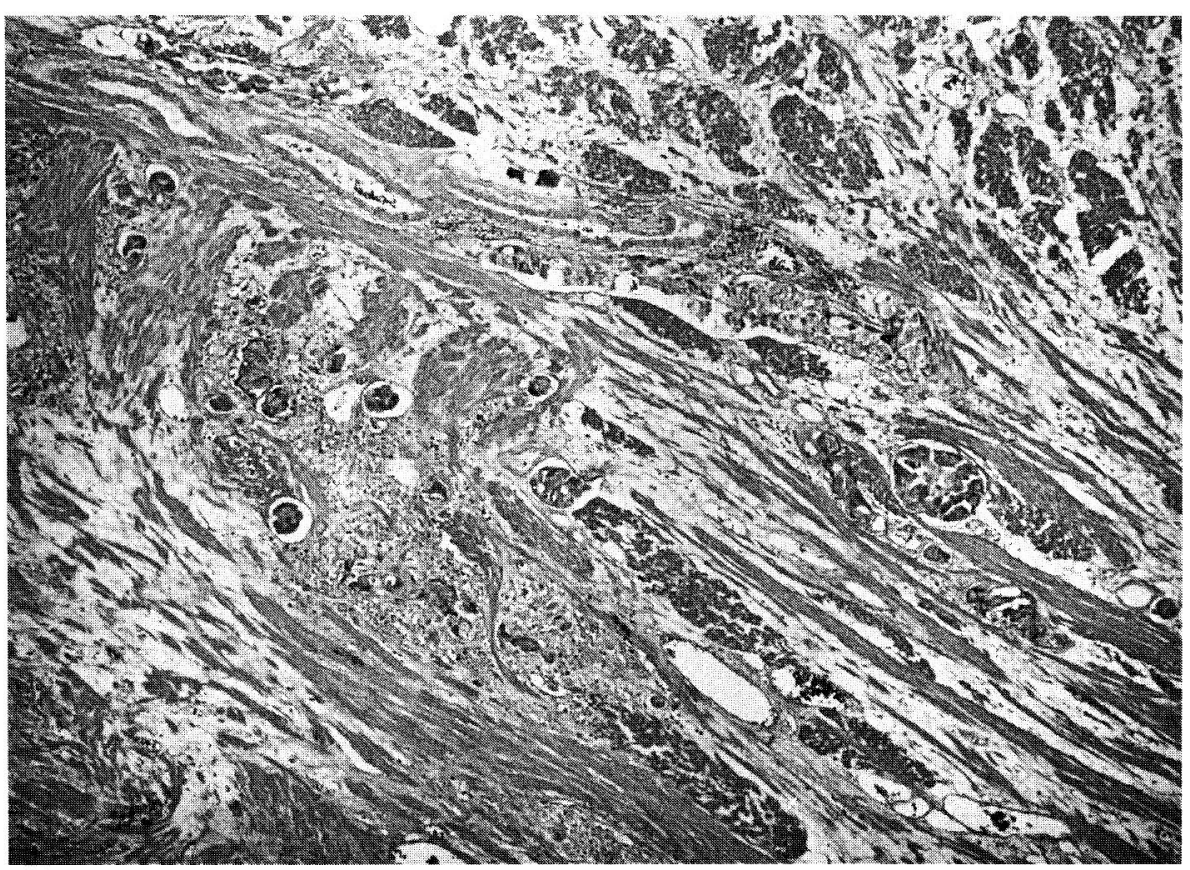


図 3 前立腺被膜の部分のリンパ管に移行上皮灙の浸潤を認める. $\mathrm{H} \& \mathrm{E}$ 染色，40倍 像.



図 4 腫瘍細胞が導管に沿って小葉構造をとるように浸潤している. H \& E 染色，40 倍像。

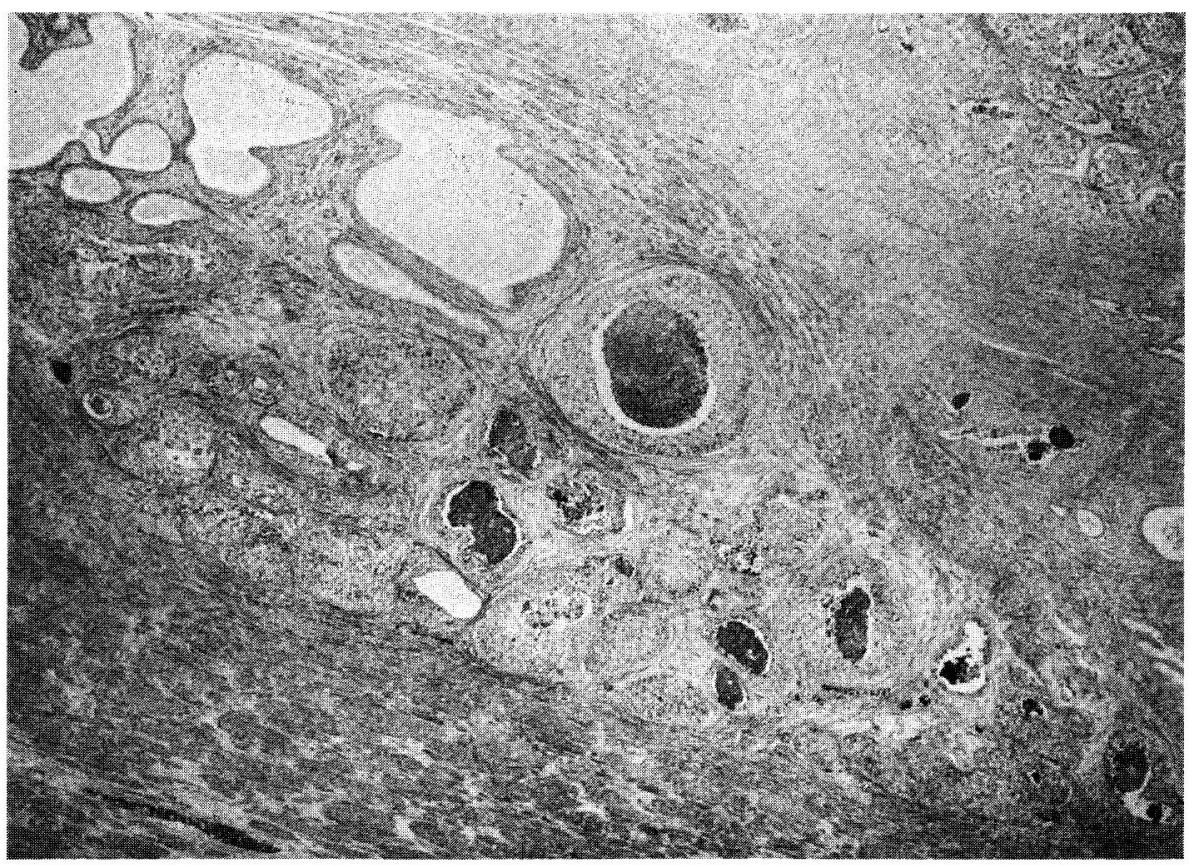


表 2 前立腺浸潤例と非浸潤例の原発巣の膀胱腫瘍の grade $の$ 比較

\begin{tabular}{c|c|c}
\hline Grade & 前立腺浸潤例 & 前立腺非浸潤例 \\
\hline TCC G3 & 8 & 25 \\
$\mathrm{G} 3>\mathrm{G} 2$ & 0 & 8 \\
$\mathrm{G} 3=\mathrm{G} 2$ & 1 & 7 \\
$\mathrm{G} 3<\mathrm{G} 2$ & 0 & 3 \\
$\mathrm{G} 2>\mathrm{G} 3>\mathrm{G} 1$ & 0 & 1 \\
$\mathrm{TCC} \mathrm{G} 3>\mathrm{SCC}$ & 1 & 0 \\
\hline $\mathrm{G} 2$ & 1 & 16 \\
$\mathrm{G} 2>\mathrm{G} 1$ & 0 & 5 \\
$\mathrm{G} 2<\mathrm{G} 1$ & 0 & 1 \\
$\mathrm{G} 1$ & 0 & 40 \\
\hline 合 計 & 11 & (N.S.)
\end{tabular}

表 3 前立腺浸潤例と非浸潤例の原発巣の膀胱腫瘍の 深達度の比較

\begin{tabular}{l|c|c}
\hline \multicolumn{1}{c|}{ 深達度* $^{\text {前立腺浸潤例 }}$} & 前立腺非浸潤例 \\
\hline pTis & 2 & 9 \\
pTa & 0 & 1 \\
pT1a & 0 & 3 \\
pT1b & 1 & 17 \\
\hline pT2 & 2 & 8 \\
pT3a & 2 & 14 \\
pTsb & 4 & 13 \\
pT4 & 0 & 5 \\
\hline \multicolumn{1}{c|}{ 合 計 } & 11 & 70 \\
\hline \multicolumn{2}{r}{}
\end{tabular}

*前立腺を除いた原発巣の膀胱腫場のみの深達度を しめす

\section{2. 前立腺浸潤例と非浸潤例の比較}

原発巣の膀胱腫瘍の grade においては grade 30成 分をふくんでいるか否かで分けて比較した(表 2 )。前 立腺浸潤例，非浸潤例ともに grade 3 を含んだ腫瘍が 半数以上を占め有意な差は認めなかった。

原発巣の膀胱腫瘍の深達度（前立腺浸潤は本来 $\mathrm{pT} 4$ であるが，ここでは前立腺を除いた膀胼局所での深達 度を比較した）においては，表在性（浸潤は粘膜下層 まで）か否かでわけて比較した（表 3 ）が，有意差は 認めなかった。膀胱全摘例を対象としているため, 当 然 high grade, high stage の割合は高くなり，有意差 は認めなかった。

原発巣の膀胱腫瘍の膀胱内での占拠部位では膀胱頸 部及び三角部を含んでいるか否かで比較した（表 4 ）。
表 4 前立腺浸潤例と非浸潤例の原発巣の膀胱腫瘍の 膀胱内占拠部位の比較

\begin{tabular}{c|c|c}
\hline $\begin{array}{c}\text { 膀腅腫瘍の位置 } \\
(\text { 占拠部位 })\end{array}$ & 前立腺浸潤例 & 前立腺非浸潤例 \\
\hline $\begin{array}{c}\text { 膀胱頝部及び三角部 } \\
\text { を含む例 }\end{array}$ & 10 & 15 \\
\hline その他 & 1 & 55 \\
\hline 合 計 & 11 & 70 \\
\hline \multicolumn{2}{|r}{} & $(\mathrm{p}<0.01)$
\end{tabular}

表 5 前立腺浸潤例と非浸潤例の原発巣のリンパ管侵 襲の有無の比較

\begin{tabular}{c|c|c}
\hline リンパ管 $(\mathrm{Ly})$ & 前立腺浸潤例 & 前立腺非浸潤例 \\
\hline $\mathrm{Ly}(+)$ & 7 & 15 \\
\hline $\mathrm{Ly}(-)$ & 4 & 55 \\
\hline 合 計 & 11 & 70 \\
\hline \multicolumn{2}{|c}{} & $(\mathrm{p}<0.01)$
\end{tabular}

前立腺浸潤例の方が膀胱頸部及び三角部を含んでいた 割合が高い傾向にあり，統計学的に有意差を認めた $(\mathrm{p}<0.01)$.

リンパ管侵襲の有無の比較では (表 5 ), 前立腺浸潤 例でリンパ管侵襲を認めた割会がたかく統計学的に有 意差を認めた $(\mathrm{p}<0.01)$.

前立腺浸潤例で pTis であった 2 例はすべて grade 3で, 膀胱頸部及び三角部を含む腫瘍であったのに対し て, 前立腺非浸潤例で pTis であった例は 9 例で，うち grade 3 で膀胱頸部及び三角部を含む腫瘍は 1 例のみ であった．症例数が少ないため有意差は認めなかった が, pTisでは, 前立腺浸潤例において grade $3 て ゙$ 膀胱 頸部及び三角部を含む例の割合が高かった。

\section{考察}

Chibber ら ${ }^{3}$ は膀胱腫瘍の前立腺浸潤を，1. Carcinoma in situ, involving prostatic urethra and ducts with or without similar bladder involvement. 2 . Noninvasive papillary tumor of prostatic urothelium and major ducts together with similar bladder tumors. 3. Invasive tumors of bladder base and neck with extension into the prostate. の三つに分類 しているが，詳細な浸潤経路についての報告は無い。 膀腅腫瘍の前立腺への浸潤経路には何通りかが考えら れる.今回の検討で，前立腺導管への浸潤のみを認め た 3 例では，浸潤は前立腺部尿道直下の導管にとど 
まっており（表 1 ), 導管を中心に腺葉に沿って小葉構 造をとっているかの如く見える例もあることから，前 立腺部尿道より導管, 腺房の順に連続的に浸潤してい く可能性が浸潤経路の一つとして考えられた. 実際今 回の検討で導管浸潤を認めた症例のうち, 前立腺部尿 道の粘膜が denudation を起こしていた 4 例を除く 5 例中 4 例で前立腺部尿道にも浸潤を認めた。また膀胱 部のリンパ液の流れは, 前立腺, 精囊などよりの流れ と合流しつつ内腸骨リンパ節に注いでいる. 我々の検 討では 8 例に前立腺リンパ管侵襲を認め, うち 2 例は リンパ管侵襲のみであった. 加えて精囊浸潤を認めた 2 例とも前立腺リンパ管侵襲を認め, うち 1 例は前立 腺への浸潤はリンパ管侵襲のみであったことより, 経 リンパ管的浸潤経路も充分考えられた。導管浸潤，リ ンパ管侵襲とも認めた例は 6 例と最も多く, 導管, リ ンパ管の両者を介して浸潤したと考えられた，以上の ことより膀胱腫瘍の前立腺への浸潤経路として, 前立 腺部尿道, 導管と連続的に浸潤する場合とリンパ管よ り浸潤する場合が考えられ，いずれか一方あるいは両 者を介して浸潤するものと考えられた。

今回の検討で, 前立腺部尿道には浸潤は無く前立腺 導管に独立した移行上皮癌を認めた例があった。原発 性前立腺移行上皮癌の頻度は諸家報告(1)3) 5) によると 前立腺悪性腫瘍の $5 \%$ 以下と少なく, 前立腺に移行上 皮癌を認めた場合, 異時性あるいは同時性に膀胼や他 の尿路上皮に移行上皮癌を認めるか, 既往があること が多い.また他の尿路上皮に carcinoma in situ (CIS) が認められることもあり ${ }^{6)}$. 多発性尿路上皮腫瘍の一 型として考えられることが多( ${ }^{115) 7)}$. したがって前立 腺移行上皮癌を認めた場合, 前立腺が原発なのか他の 尿路上皮が原発なのか病理学的に判断するのは困難で ある. 前立腺移行上皮癌の発生母地について Kirk ら ${ }^{8)}$ は33例の前立腺移行上皮癌の検索結果より導管より発 生すると報告している. 古里 ${ }^{9}$ は前立腺導管内発育を 示す癌について免疫染色を施行しその結果 PSA, $\mathrm{PAP}$ と陽性の腺癌, ともに陰性の移行上皮癌, PSA 弱陽性で PAP が陰性の腺癌と移行上皮癌の中間型と 思われるような例の 3 型に分けられると報告してい る。このことは導管の基底細胞は腫瘍化の過程におい て腺上皮と移行上皮の 2 方向, あるいはその中間型の 分化をしていく可能性があることを示唆しており， Kirk ら ${ }^{8)}$ の報告をうらずけている。これらのことより 考えて, 移行上皮癌の多中心性発生の一型として膀胱 腫瘍と同時に前立腺にも移行上皮癌が発生することも
少なからずあると考えられる，すなわち，膀胱と前立 腺（特に導管内）に同時に移行上皮癌を認めた場合， 膀胱原発の移行上皮癌の前立腺浸潤か, 移行上皮癌の 多中心性発生の一型か鑑別することは困難で，両者の 可能性があることは否定できないと考えられる.

膀胱腫媓の前立腺への浸潤経路は前述の如く主に, 経導管的連続浸潤, 経リンパ管浸潤, 混合型の 3 型で ある。したがって原発巣が膀胱頸部や三角部を含んで いたりリンパ管侵襲がある場合, 前立腺への浸潤が存 在する可能性が高くなると予想される．前立腺浸潤例 と非浸潤例の比較においては, 原発巣の grade, 深達度 では両者に差は無かったが，膀胱頸部及び三角部を含 む例，リンパ管侵襲を認めた例の割合は有意に前立腺 浸潤例に高かった。したがってこのような症例におい ては，前立腺への浸潤の可能性を充分念頭において診 断, 治療をする必要があろう.また $\mathrm{pT}$ is 症例において は有意差こそが無かったものの grade 3で膀胱頸部及 び三角部を含んでいる割合が前立腺浸潤例に高い傾向 にあり，また前立腺浸潤例は CIS の natural history

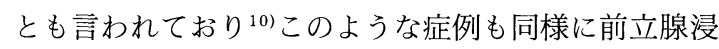
潤に注意する必要があると考えられる.

\section{結語}

膀胱腫場の前立腺への浸潤経路としては, 1. 経導管 的連続浸潤，2. 経リンパ管浸潤，3. 混合型，の 3 型 が考えられた。また，膀胱移行上皮癌症例において前 立腺にも移行上皮癌（特に導管内）を認めた場合，膀 胱原発癌の前立腺浸潤と移行上皮癌の多中心性発生の 一型の両者の可能性があると考えられた。

前立腺浸潤例において, 原発巣が膀胱頸部及び三角 部を含む腫瘍の割合とリンパ管侵襲を認めた割合が有 意に高く，このような例では前立腺浸潤を充分念頭に おいた診断, 治療が必要と考えられた。

\section{文献}

1) Schellhammer, P.F., Bean, M.A. and Whitmore, W.F.Jr.: Prostatic involvement by transitional cell carcinoma.: Pathogenesis, patterns and prognosis. J. Urol., 118, 399-403, 1977.

2) 高井計弘, 垣添忠生, 蔦巣賢一, 松本恵一, 岸紀代 三: 前立腺移行上皮癌症例抢上び膀胱移行上皮癌 の前立腺浸潤例の検討. II) 膀胱移行上皮癌の前立 腺浸潤例との対比. 日泌尿会誌, 78, 1372-1378, 1987.

3) Chibber, P.J., Mcintyre, M.A., Hindmarsh, J.R., Hargreave, T.B., Newsam, J.E. and Chisholm, G.D.: Transitional cell carcinoma involving the prostate. Brit. J. Urol., 53, 605-609, 1981. 
4) Kopelson, G., Harisiadis, L., Romas, N.A., Veenema, R.J. and Tannenbaum, M. : Periur ethral prostatic duct carcinoma. Cancer, 42, 2894-2902, 1978.

5) Wolfe, J.H.N. and Lloyd-davis, R.W.: The management of transitional cell carcinoma in the prostate. Brit. J. Urol., 53, 253-257, 1981.

6) Schujman, E., Mukamel, E., Siutzker, D., Mor, C. and Seruvadio, C.: Prostatic transitional cell carcinoma : Concept of its pathogenesis and classification. Israel J. Med. Sciences, 19, 794800, 1983.

7) Karpas, C.M. and Moumgins, B : Primary transitional cell carcinoma of prostate gland: Possible Pathogenesis and relationship to reserve cell hyperplasia of prostatic periureth. ral ducts. J. Urol., 101, 201-205, 1069.

8) Krik, D., Christine, E.H. and Shaldon, C.: Transitional cell carcinoma of the prostate. Brit, J. Urol., 51, 575-578, 1979.

9）古里征国：前立腺末分化癌の組織化学的検討. 東 京慈恵会誌，98，69-70，1984.

10）長船匡男, 伊藤 博, 有馬正明, 松田 稔, 水谷修 太郎：前立腺におよぶ原発性膀胱上皮内癌. 日泌 尿会誌，71，257-263，1980。

（1996年 5 月21日受付，1997年 1 月22日受理） 